\title{
Güvenli Turizm Sertifikalı İşetmelerin Profilleri ve Sertifikaya Sahip Konaklama İsletmelerine Yönelik Çevrimiçi Misafir Yorumlarının Değerlendirilmesi
}

\author{
Tuba Türkmendağ ${ }^{1 * *}$ BD Barış Erdem ${ }^{2}$ (D) Suat Akyürek ${ }^{3}$ (i) \\ ${ }^{1}$ Atatürk Üniversitesi, Turizm Fakültesi, Erzurum, Türkiye, tuba.gezen@hotmail.com, ORCID: 0000-0003-1528-2883 \\ ${ }^{2}$ Balıkesir Üniversitesi, Turizm Fakültesi, Balıkesir, Türkiye, berdem2110@gmail.com, ORCID: 0000-0003-1560-2883 \\ ${ }^{3}$ Gümüşhane Üniversitesi, Sosyal Bilimler Meslek Yüksekokulu, Gümüşhane, Türkiye, suat.akyrek@gmail.com, ORCID:0000-0002-8552-5695
}

Öz

Araştırma Makalesi

Bu araştırmada, Türkiye'de güvenli turizm sertifikasına sahip işletmelerin profillerinin ortaya çıkarılması ve güvenli turizm sertifikalı konaklama işletmelerine yönelik olarak misafirlerin çevrimiçi yorumlarının incelenmesi amaçlanmıştır. Işsletme profillerinin ortaya çıkarılmasında Türkiye Turizm Tanıtım ve Geliştirme Ajansı ve T.C. Kültür ve Turizm Bakanlığı'nın verilerinden faydalanılmıştır. 5084 işletmenin incelendiği araştırma sonucunda; Türkiye'de güvenli turizm sertifikasına sahip işletmelerin yoğun olarak Istanbul'da faaliyet gösterdiği, güvenli turizm sertifikalı tesislerin büyük çoğunluğunu konaklama işletmelerinin oluşturduğu ve güvenli turizm sertifikasına sahip işletmelerin yarısından çoğunun belediye belgeli tesis niteliğinde olduğu tespit edilmiştir. Güvenli turizm sertifikalı konaklama işletmelerinin uygulamalarına ilişkin olarak ise, misafirlerin yorumlarının genel itibariyle olumlu yönde olduğu sonucuna ulaşılmıştır. Olumlu yorumların ağırlıklı olarak işletmedeki temizlik ve hijyen uygulamaları konusunda olduğu; olumsuz yorumlarda ise temizlik ve hijyen uygulamalarının yetersizliği ile maske kullanılmamasına vurgu yapıldığı saptanmıştır. Ayrıca misafirlerin büyük çoğunluğu konaklama işletmelerinin almış oldukları tedbirler sayesinde kendilerini güvende hissettiklerini ve huzurlu ve rahat bir tatil geçirdiklerini vurgulamışlardır.

Anahtar Kelimeler: Covid-19 Salgını, Çevrimiçi Misafir Yorumları, Hijyen, Güvenli Turizm Sertifikası, Turizm

\section{Profiles of Businesses with Safe Tourism Certificate and Evaluation of Online Guest Comments for Certified Accommodation Businesses}

\begin{abstract}
In this study, it was aimed to reveal the profiles of tourism businesses with safe tourism certificates in Turkey and to examine online guest comments for safe tourism-certified accommodation businesses. The data of Turkey Tourism Promotion and Development Agency and Republic of Turkey Ministry of Culture and Tourism has been used. As a result of the research where 5084 enterprises were examined, it was determined that the enterprises with safe tourism certificates in Turkey operate intensively in Istanbul, the majority of the safe tourism certified facilities are comprised of accommodation enterprises and more than half of the enterprises with safe tourism certificates are municipal certified facilities. Regarding the practices of safe tourism-certified accommodation businesses, it was concluded that the comments of the guests were generally positive. It has been determined that the positive comments are predominantly about the cleaning and hygiene practices in the establishment, while the negative comments are emphasized by the inadequacy of cleaning and hygiene practices and not using mask. In addition, the majority of the guests emphasized that they felt safe and had a peaceful and comfortable holiday thanks to the precaution taken by the accommodation businesses.
\end{abstract}

Keywords: Covid-19 Pandemic, Hygiene, Online Guest Comments, Safe Tourism Certificate, Tourism

Received : 01.06.2021

Revision1: 10.09.2021

Accepted: 20.09.2021

\section{Önerilen Atıf/Suggested Citation}

Türkmendağ, T., Erdem, B. ve Akyürek, S. (2021). Güvenli Turizm Sertifikalı İşletmelerin Profilleri ve Sertifikaya Sahip Konaklama İşletmelerine Yönelik Çevrimiçi Misafir Yorumlarının Değerlendirilmesi. Güncel Turizm Araştırmaları Dergisi, 5(2), 455-476.

**Sorumlu yazar e-posta: tuba.gezen@hotmail.com 


\section{GíRiş}

Hijyen, insan sağlığının korunması ve geliştirilmesi ile ilgilenen bir bilim olarak kabul edilmektedir (Notermans ve Powell, 2005; Göktan ve Tunçel, 2016). Bununla birlikte hijyen, gida kaynaklı hastalıkların ve yaralanmaların ya da gıda bozulmalarının ekonomik sonuçlarından kaçınmak için kritik önem taşımaktadır. Diğer yandan turizm kırılgan yapısı nedeniyle krizlerden, salgınlardan, savaşlardan ve afetlerden en fazla ve hızlı şekilde etkilenen sektörlerin başında geldiğinden (Çetinkaya vd., 2020), bu sektörde hijyen ve güvenlik konuları ayrı bir önem arz etmektedir. Turizm sektöründe hijyen kurallarına uyulmaması sonucunda müşteri ve prestij kaybı, ek maliyetler, satışlarda azalma gibi olumsuz sonuçlar ortaya çıkabilmektedir (Yılmaz, 2012: 314). İlgili yazında da (Marwaha, 2007; Bauer, 2008; Sanlıer vd., 2010; Arendt vd., 2014; Göktan ve Tunçel, 2016) gerek siyasi otoritenin gerekse üreticilerin/işletmelerin tüketiciler için güvenli ürün sunumunu yerine getirebilme ve hijyen koşullarına uygun ortamları sağlama sorumluluklarının olduğu vurgulanmaktadır.

Turizm sektörü açısından bakıldığında; doğal çevre, sektörde yer alan işletmeler ve bu işletmelerin etkileşimde bulunduğu tedarikçiler, sektörde çalışan işgörenler, kullanılan her türlü araç-gereç ve ekipman için birtakım hijyen önlemlerinin alınması gerekmektedir (Yllmaz, 2012; Aktaş ve Özdemir, 2012). Literatürde hijyen ile ilgili oldukça fazla çalışmanın bulunması konunun önemine işaret etmektedir. $\mathrm{Bu}$ bağlamda hijyen çalışmaları; personel hijyeni (Notermans ve Powell, 2005; Yılmaz, 2012; Göktan ve Tunçel, 2016; Bulduk ve Bulduk, 2018), üretim ve tüketim alanlarının hijyeni (Marwaha, 2007; Aktaş ve Özdemir, 2012), kullanılan araç gereç ve ekipmanların hijyen ve sanitasyonu (Notermans ve Powell, 2005; Yılmaz, 2012; Aktaş ve Özdemir, 2012), çevre hijyeni (Bauer, 2008; Wang vd., 2020), gıda hijyeni (Notermans ve Powell, 2005; Marwaha, 2007; Aktaş ve Özdemir, 2012; Göktan ve Tunçel, 2016), depolama alanlarının hijyeni (Marwaha, 2007), personelin hijyen alg1sı/bilgisi ve eğitimi (Sanlıer vd., 2010; Arendt vd., 2014; Giritlioğlu ve Kızılcık, 2016) üzerine odaklanmaktadır. Turizm sektöründe de spesifik olarak konaklama işletmelerinde (Sanlıer vd., 2010; Aktaş ve Özdemir, 2012; Dündar vd., 2020), otellerde kat hizmetlerinde (Akoğlan Kozak, 1997; Dündar vd., 2020), restoran işletmelerinde (Aktaş ve Özdemir, 2012; Chang vd., 2021), pastane işletmelerinde (Giritlioğlu ve Kızılcık, 2016), Türk hamamlarında (Açıksözlü ve Bozok, 2018) ve kruvaziyer gemilerde (Shuting vd., 2018) hijyen üzerine yapılan çalışmalar mevcuttur.

İnsanlık tarihinde birçok önemli salgın süreci yaşanmıştır. 20. yüzyıla bakıldığında 1918-1919'da "İspanyol gribi", 1957-1958'de "Asya gribi" ve 1968-1969'da "Hong Kong gribi" gibi salgınlar yaşanmıştır (Özkoçak vd., 2020). 21. yüzyılda ise SARS (2003), domuz gribi (2009), ebola (2014), MERS (2015) gibi salgınlar yaşanmış ve her salgın sürecinde turizm sektörü olumsuz etkilenmiştir (Çetinkaya vd., 2020; Gössling vd., 2021). 2019 yılında Çin'in Vuhan kentinde ortaya çıkan ve tüm dünyaya yayılan covid-19 salgını (Koronavirüs salgını) tüm insanlığı etkilemekle birlikte, bu salgının etkisi küresel düzeyde hala devam etmektedir. Covid-19 salgını turizm sektörünü de küresel ölçekte durma noktasına getirmiştir. Bu kapsamda, sektörde yer alan 
işletmelerin faaliyetlerini sürdürebilmesi için gerek turistlere gerekse sektörde çalışanlara güvenli ortamlar sağlanması gerekliliği ortaya çıkmıştır. Güvenli turizm ortamlarının sağlanabilmesi için turistlerin ziyaretleri esnasında hizmet aldı̆̆ı tüm faaliyet alanlarında virüsün bulaşmasını ve yayılmasını engelleyecek hijyen önlemlerinin alınması ve sağlığı tehdit eden risk durumlarının en aza indirilmesi gerekmektedir (Çetinkaya vd., 2020). Bu durum konuyla ilgili olarak gerek kamu gerekse özel sektör düzeyinde etkin bir çaba göstermeyi ve eşgüdüm içinde çalışmayı gerekli kılmaktadır.

Hijyen konusu turizm sektörü açısından kritik bir öneme sahiptir. Öyle ki gerek covid19 salgını öncesi yapılan çalışmalarda (Akoğlan Kozak, 1997; Notermans ve Powell, 2005; Marwaha, 2007; Bauer, 2008; Sanlier vd., 2010; Y1lmaz, 2012; Arendt vd., 2014; Jovanović vd., 2015; Göktan ve Tunçel, 2016; Gül vd., 2018; Shuting vd., 2018; Açıksözlü ve Bozok, 2018) gerekse covid-19 salgını sürecinde yapılan çalışmalarda (Mostafanezhad, 2020; Erdoğan ve Yamaç Erdoğan, 2020; Karadeniz vd., 2020; Yazıc1 Ayyıldız, 2020; Özaltın Türker ve Ertürk, 2020; Naumov vd., 2020; Sezen Doğancılı, 2020; Dündar vd., 2020; Kaushal ve Srivastava, 2021; Chang vd., 2021) turistlerin işletmelerden öncelikli beklentilerinden biri olarak hijyen konusunun geldiği belirtilmektedir. Buna rağmen, işletmelerde hijyen ve sanitasyon açısından birtakım yetersizliklerin olduğu birçok çalışmada ortaya koyulmuştur (Giritlioğlu ve Kızılcık, 2016; Bulduk ve Bulduk, 2018; Açıksözlü ve Bozok, 2018; Akyürek ve Kutukız, 2020). Dolayısıyla salgın sürecini en az hasarla atlatmak isteyen ülkeler birtakım arayışlara girmişlerdir. Bu arayışların sonucunda Türkiye'de salgın sürecinde "Güvenli Turizm Sertifikası" adı altında bir uygulamaya geçilmiştir. Nitekim yerli yazındaki bazı araştırmalarda, Türkiye'de turizm hareketlerine katılan turistlerin güvenli turizm sertifikasına sahip olan turizm işletmelerine daha fazla güven duydukları tespit edilmiştir (Yazıcı Ayyıldız, 2020; Dündar vd., 2020; Eşitti ve Özdemir, 2020). Dolayısıyla turizm sektöründe turistlere "güvenli turizm" ortamı sağlayabilen ülke ve işletmelerin daha fazla tercih edileceği düşünülebilir. Bu bağlamda Türkiye'de uygulamaya koyulan güvenli turizm sertifikasının güvenli turizm ortamı oluşturulmasına katkı sağlayacağı düşünülmektedir. Bu ise, söz konusu sertifikanın yaygın bir şekilde kullanım alanı bulabilmesine bağlıdır. Bu kapsamda, yapılan bu çalışmanın temel amacı, Türkiye'de güvenli turizm sertifikasına sahip turizm işletmelerinin genel profilini ve güvenli turizm sertifikalı konaklama işletmelerini ziyaret eden turistlerin yapmış oldukları çevrimiçi yorumlara dayanarak deneyimlerini ortaya koymaya çalışmaktır. Böylece, Türkiye'de turizm sektöründe faaliyet gösteren ilgili kurum, kuruluş ve uygulayıcılara yönelik değerlendirme ve önerilerde bulunulması amaçlanmıştır.

İlgili yazında Türkiye'de güvenli turizm sertifikasına sahip işletmelerin profillerinin ortaya koyulduğu ve güvenli turizm sertifikalı konaklama işletmeleri özelinde çevrimiçi misafir yorumlarının incelendiği başka bir çalışmaya rastlanamamıştır. Bu tespitimiz, yürütülen bu araştırmanın özgünlüğü açısından önem taşımaktadır. Bu bağlamda, araştırma bulgularının ilgili yazına ve paydaşlara fayda sağlaması beklenmektedir. 


\section{Kavramsal Çerçeve}

2019 yılında ortaya çıkan ve bütün dünyayı etkileyen covid-19 salgını tüm sektörleri doğrudan veya dolaylı olarak etkilemiştir. Turizm sektörü de salgının ilk ortaya çıktığ1 andan itibaren en fazla etkilenen sektörlerden biridir. Günümüzde turizm sektörünün dünya ekonomisine katkıları ve toplumsal yaşamdaki rolü dikkate alındığında, dünyadaki birçok ülkenin covid-19 salgınının turizme olan etkilerini en aza indirebilmek için yoğun çaba gösterdiklerine tanık olunmaktadır. Bu kapsamda, Türkiye Turizm Tanıtım ve Geliştirme Ajansı tarafından yürütülen “Güvenli Turizm Sertifikası" Türkiye'deki turizm işletmelerinin salgın sürecinde faaliyetlerini sağlıklı bir şekilde yürütebilmesini sağlayan önemli bir sertifikasyon programı olarak kabul edilmektedir.

İşletmelerin gereksinimlerine uygun olarak ürün, süreç veya yönetim biçiminin üçüncü şahıslar tarafından yazılı olarak garanti altına alınması ile ilgili işlemler bütününe sertifikasyon denilmektedir (Demir ve Çevirgen, 2006). Turizm sektöründe farklı konu alanlarına yönelik sertifikasyon ve derecelendirme uygulamalarına yaygın olarak rastlanmaktadır. Bu tür uygulamalar başta genel standartlara yönelik (ISOInternational Organization for Standardization) olmakla birlikte, g1da hijyeni ve sanitasyona (HACCP-Hazard Analysis and Critical Control Points), iş sağllğ 1 ve güvenliğine (OHSAS 18001), çevreye/sürdürülebilirliğe (yeşil yıldız, yeşil anahtar, beyaz yıldız, travelife, mavi bayrak), işletme konseptine (helâl sertifika) ve personel eğitimine yönelik (servis görevlisi hijyen eğitimi gibi) verilebilmektedir. Güvenli turizm sertifikası da covid-19 salgını döneminde Türkiye'de turizm sektörünün faaliyetlerini sağlıklı bir biçimde gerçekleştirebilmesi için uygulanmaya başlanan ve Türkiye'deki konaklama tesisleri; restoranlar/kafeler; sağlık, kültür, sanat ve kongre tesisleri; deniz turizmi tesisleri, temalı parklar; mekanik hat tesisleri ve tur ve transfer araçlarını kapsayan bir sertifikasyon sistemidir (Türkiye Turizm Tanıtım ve Geliştirme Ajansı, 2021b). Bu sertifikasyon sisteminin etkin bir şekilde uygulanmasının, covid-19 salgını döneminde Türkiye'ye yönelik iç ve diş turizm talebini olumlu yönde etkileyeceği ve bu sertifikaya sahip olan işletmelere de hijyen tedbirleri açısından uzun vadede rekabet gücü kazandırabileceği düşünülmektedir. Nitekim Eşitti ve Özdemir (2020), güvenli turizm sertifikasına sahip olmayan otel işletmelerinin mevcut müşterilerini kaybetme riskiyle karşı karşıya kalacaklarını ifade etmektedir. Yazarlar ayrıca turistlerin ve çalışanların sağlıklarının güvende olacağı işletmeleri tercih edeceklerine dikkat çekmektedir. Jovanović ve arkadaşları (2015) ise, destinasyonların turistler için sunmuş olduğu hijyenik veya güvenli turizm ortamlarının önemli bir rekabet avantajı sağladığını vurgulamaktadır. Bu bağlamda, günümüzde hijyenin turizm sektörü açısından anahtar bir unsur olarak görülebileceği ve güvenli turizm sertifikasının Türk turizm sektörü için fırsata dönüştürülebileceği öngörülebilir.

Turizm sektöründe sertifikasyon uygulamaları başta turistler açısından olmak üzere, işletmeler, hükümet, toplum ve çevre gibi çeşitli perspektiflerden birçok avantaj sağlamaktadır (Satar ve Güneş, 2017). Karaçor ve Tanrısever (2020), işletmeye kattığı imaj, rekabet üstünlüğü, pazarlama ve tanıtmaya olan olumlu etkisi gibi nedenlerin 
turizm işletmelerinde sertifikaların tercih edilmesinde önemli olduğunu belirtmişlerdir. Bununla birlikte, Satar ve Güneş (2017) yapmış oldukları çalışmada, sertifikasyonun, yoğun rekabet ortamında işletmelere pazarlama açısından marka, standartlaştırma ve güvenilirlik unsurlarını sağlayabildiğini ileri sürmüşlerdir.

Bazı yazarlar (Bauer, 2008; Jovanović vd., 2015), turistler açısından destinasyon seçiminde sağlık ve hijyen konusunun oldukça önemli rol oynadığını dile getirmektedir. Birçok araştırmacı (Mostafanezhad, 2020; Demir, 2020; Erdoğan ve Yamaç Erdoğan, 2020; Karadeniz vd., 2020; Kaushal ve Srivastava, 2021; Gössling vd., 2021) covid-19 salgınının daha önce uygulanmakta olan turizm faaliyetlerini yeniden şekillendireceğini ileri sürmektedir. Bu kapsamda ilgili yazındaki pek çok araştırmada (Erdoğan ve Yamaç Erdoğan, 2020; Akyürek ve Kutukız, 2020; Sezen Doğancıl1, 2020; Özaltın Türker ve Ertürk, 2020; Kaushal ve Srivastava, 2021) turistlerin gelecek dönemlerde hijyen güvenliğine/standartlarına daha fazla önem verecekleri vurgulanmaktadır. Nitekim Naumov ve arkadaşlarının (2020) Bulgaristan'da yapmış oldukları çalışmada, gelecek yıllarda turistlerin seyahat tercihlerinde sanitasyon ve hijyenin daha etkili olacağ (2020) Türkiye'de yapmış oldukları diğer bir çalışmada, gelecek dönemlerde turistlerin beklenti ve talepleri ile ilgili olarak ürün standartlarında değişim yaşanacağı ve işletmelerin özellikle hijyen prosedürlerinde daha şeffaf ve yenilikçi bir tavır sergileyecekleri belirtilmektedir.

Türkiye' de güvenli turizm sertifikası, başta Kültür ve Turizm Bakanlığı olmak üzere Sağlık, Ulaştırma, İçişleri ve Dışişleri Bakanlıklarının ortak çalışmaları sonucunda oluşturulmuştur. Bununla birlikte, tüm sektör paydaşlarının iş birliğini de kapsayan güvenli turizm sertifikasyon programı covid-19 salgını dönemi için önemli bir adım olarak görülmektedir (Eşitti ve Özdemir, 2020). Güvenli turizm sertifikası, tatilini Türkiye' de geçirecek olan turistler için ulaşımdan konaklamaya, tesis çalışanlarından, yolcuların kendi sağlık durumuna kadar uzanan geniş bir yelpazede alınması önerilen önlemleri içermektedir (Türkiye Turizm Tanıtım ve Geliştirme Ajansı, 2021a). Benzer şekilde Eşitti ve Özdemir de (2020), sertifika programının, Türkiye'yi ziyaret eden turistlerin ulaşımlarına, konaklamalarına ve aynı zamanda turizm çalışanlarının da sağlık durumlarına yönelik tedbirleri kapsadığını belirtmektedir. Demir (2020) ise, güvenli turizm sertifikası kapsamında alınan önlemlerin turizm sektörünün covid-19 salgın sürecini daha az hasarla atlatması, tesislerin ayakta kalabilmesi ve çalışanların mali anlamda yükünü azaltması adına yararlı olduğunu, ancak yeterli olmadığını öne sürmektedir. Yazar çalışmasında ayrıca, salgın sonrası hiçbir şeyin eskisi gibi olmayacă̆ından dolayı turizm sektörünün de dünyadaki değişime uygun önlemler alması gerektiğinden bahsetmektedir.

Güvenli turizm sertifikası Türkiye'de 01.01.2021 tarihinden itibaren oda sayısı 30 ve üzeri olan konaklama tesisleri için zorunlu olmakla birlikte, oda sayısı 30'dan az olan konaklama tesisleri ve diğer alanlar için isteğe bağlıdır (Türkiye Turizm Tanıtım ve Geliştirme Ajansı, 2021a). Güvenli turizm sertifikası alan işletmeler, sertifikayı aldığını gösteren logo veya işaretleri tüm misafirlerin ve çalışanların görebileceği alanlara 
asarak ve misafirlerin belge üzerindeki kare kodu okutmasıyla tesis ile ilgili tüm denetleme bilgilerine ulaşabilmelerini sağlamaktadır (Türkiye Turizm Tanıtım ve Geliştirme Ajansı, 2021a). Böylece otel işletmeleri misafir ve çalışanlarına karşı güven ortamı yaratarak, belgeyi satış ve pazarlama faaliyetleri için de kullanabilmektedir (Yazıcı Ayyıldız, 2020). Güvenli turizm sertifikasına yönelik her bir tesis için türüne göre farklı başlıklar ve kriterler belirlenmiştir. Salgın süresince uygulanması planlanan covid-19 ve hijyen uygulamalarının ana başlıkları genel olarak Tablo 1'de yer almaktadır (Türkiye Turizm Tanıtım ve Geliştirme Ajansı, 2021c):

Tablo 1. Salgın süresince uygulanması planlanan Covid-19 ve hijyen uygulamaları

\begin{tabular}{|c|c|}
\hline $\begin{array}{l}\text { Zorunlu uygulamalar (süreç yönetimi, standartların } \\
\text { belirlenmesi, protokollerin hazırlanması) }\end{array}$ & $\begin{array}{l}\text { Genel alanlarla ilgili uygulamalar (odalar, } \\
\text { mutfaklar, yeme-içme üniteleri, yüzme havuzları } \\
\text { ve plajlar, fitness salonları ve spa, animasyon } \\
\text { salonları, mini kulüp, lavabo ve tuvaletler) }\end{array}$ \\
\hline Vale hizmeti ile ilgili düzenlemeler & Misafirin tesislere girişi ile ilgili kurallar \\
\hline Güvenlik ile ilgili uygulamalar & Otel taşıtları ile ilgili uygulamalar \\
\hline $\begin{array}{l}\text { Personel konaklama üniteleri ve lojmanlar ile ilgili } \\
\text { uygulamalar }\end{array}$ & Personel için alınacak önlem ve uygulamalar \\
\hline Atık yönetimi ile ilgili uygulamalar & Araç içi uygulamalar \\
\hline $\begin{array}{l}\text { Satın alma, mal kabulü ve depolama ile ilgili } \\
\text { uygulamalar }\end{array}$ & Acil durum ve izolasyon ile ilgili uygulamalar \\
\hline Tabela, logo, sertifika ve QR ile ilgili uygulamalar & $\begin{array}{l}\text { Covid-19 testi ve numune alma işlemleri ile ilgili } \\
\text { uygulamalar }\end{array}$ \\
\hline Kayak odaları ve mekanik hatlar ile ilgili uygulamalar & $\begin{array}{l}\text { Haşere ve zararlılarla mücadele ile ilgili } \\
\text { uygulamalar }\end{array}$ \\
\hline $\begin{array}{l}\text { Yatçı/kruvaziyer yolcu kullanım alanlarındaki } \\
\text { uygulamalar (yat çekek alanı-bakım ve onarım } \\
\text { birimleri, yatçı eşya depoları/dolapları) }\end{array}$ & \\
\hline
\end{tabular}

Güvenli turizm sertifikası kapsamında covid-19 ve hijyen uygulamaları değerlendirildiğinde, kriterlerin birçoğunun genel hijyen kuralları kapsamında salgın öncesinde de uyulması gereken kurallar olduğu dikkati çekmektedir. Bununla birlikte, Türkiye'de tüm turizm işletmelerinin güvenli turizm sertifikasına sahip olmasının turizmde rakip ülkelerle rekabet açısından önem arz ettiği düşünülmektedir.

\section{YÖNTEM}

Bu araştırmada Türkiye' de güvenli turizm sertifikasına sahip işletmelerin profilleri ile güvenli turizm sertifikalı konaklama işletmelerini ziyaret eden yerli ve yabancı turistlerin Tripadvisor internet sitesine bıraktıkları yorumlar incelenmiştir. Araştırmada elde edilen verilerin analiz edilmesinde birinci aşamada nicel yöntemlerden, ikinci aşamada ise nitel yöntemlerden yararlanılmıştır. Buna göre birinci aşamada, Türkiye Turizm Tanıtım ve Geliştirme Ajansı resmi internet sayfasında yer alan bilgilerden yararlanılarak güvenli turizm sertifikasına sahip olan işletmeler ile ilgili verilerin analizinde nicel yöntemler kullanılmıştır. Araştırmanın amacı doğrultusunda, birinci aşamada T.C. Kültür ve Turizm Bakanlığı ile Türkiye Turizm Tanıtım ve Geliştirme Ajansı'nın resmi internet sayfalarında Türkiye'de 
faaliyet gösteren ve güvenli turizm sertifikası programına tabi olan işletmeler aşağıdaki gibi gruplandırılmıştır:

- Konaklama tesisleri (T.C. Kültür ve Turizm Bakanlığı belgeli konaklama tesisleri, belediye belgeli konaklama tesisleri ve diğer konaklama tesisleri)

- Restoran/kafe (T.C. Kültür ve Turizm Bakanlığı belgeli restoran/kafe tesisleri, belediye belgeli restoran/kafe tesisleri ve diğer restoran/kafe tesisleri)

- Kültür, sanat ve kongre tesisleri

- Deniz turizmi tesisleri

- Temali parklar

- Mekanik hat tesisleri

- Tur ve transfer araçları

Öte yandan, turistlerin çevrimiçi seyahat sitelerinde paylaşmış oldukları yorumlar ağırlama sektöründe pazarlama anlayışını yeniden şekillendirmek ve karar almayı desteklemek için önemli fırsatlar sunmaktadır (Xiang vd., 2015). Thanh ve Kirova (2018) turistlerin seyahatlerini planlamada, seyahatlerinde faydalanacakları hizmet sağlayıcılarını (konaklama, ulaşım, yeme-içme vb.) seçmede ve seyahat sonrasında izlenimlerini paylaşmada sosyal ağları giderek daha fazla kullandıklarını ileri sürmektedir. Bu nedenle turistlerin çevrimiçi yapmış oldukları yorumların turizm araştırmalarında veri olarak kullanımı son yıllarda artış göstermiş ve önemli bir veri madeni olarak kabul görmüştür. Dünyanın en büyük seyahat platformu olan Tripadvisor her ay 463 milyon turiste hizmet vermektedir. Dünyanin her yerinden turistler, Tripadvisor internet sitesini ve uygulamasını kullanarak 859 milyonu aşkın yoruma erişebilmektedir (Tripadvisor, 2021). Bu bağlamda araştırmanın ikinci aşamasında Türkiye' deki güvenli turizm sertifikalı konaklama işletmelerini ziyaret eden yerli ve yabancı turistlerin tripadvisor.com' da yer alan güvenli turizm sertifikası ile ilgili çevrimiçi yorumları incelenmiştir. Böylece, covid-19 salgını döneminde Türk turizm sektöründe önemli bir uygulama olarak görülen güvenli turizm sertifikası kapsamında sertifikalı konaklama işletmelerinin misafirlerin yapmış oldukları çevrimiçi paylaşımlarda nasıl değerlendirildiğinin tespit edilmesi amaçlanmıştır.

\section{Veri Toplama Süreci ve Verilerin Analizi}

Birinci aşamada, güvenli turizm sertifikasına sahip turizm işletmelerinin profillerini ortaya koymak amacıyla araştırmanın verileri Türkiye Turizm Tanıtım ve Geliştirme Ajansı resmi internet sayfasında yer alan bilgilerden yararlanılarak 24 Mart-22 Nisan 2021 tarihleri arasında toplanmıştır. Tekrar eden işletmelerin verileri sadece bir kez araştırmaya dâhil edilmiş ve veri toplama süreci içerisinde veri toplama işlemi geriye dönülmeden gerçekleştirilmiştir. Araştırma verilerinin toplandığı dönemde Türkiye'de güvenli turizm sertifikası almış toplam işletme sayısı 6522'dir. Belgelendirme süreci devam eden 230 işletme araştırmanın kapsamı dışında tutulmuştur. Bununla birlikte, içerdiği bilgilerin (bu kategoride sadece; plaka numarası, aracın kayıtlı olduğu yetki belgesi, koltuk sayısı, araç cinsi sertifika tarihi 
bilgileri yer almaktadır) araştırmanın amacına uygun nitelikte olmamasından dolayı, güvenli turizm sertifikasına sahip tur ve transfer araçlarına (1438 işletme) ait bilgiler de veri toplama sürecine dâhil edilmemiştir. Böylece toplamda 5084 işletme bu araştırmanın veri tabanını oluşturmuştur. Verilerin analizinde SPSS 20 paket programı kullanılmıştır. Bu aşamada, çeşitli değişkenlere ilişkin frekans analizi sonuçlarına yer verilmiştir.

Araştırmanın ikinci aşamasında güvenli turizm sertifikalı konaklama işletmelerine yönelik yerli ve yabancı turistlerin tripadvisor.com internet sitesinde İngilizce ve Türkçe dilinde yaptığı yorumları 29 Nisan-7 Mayıs 2021 tarihleri arasında incelenmiştir. Araştırmada güvenli turizm sertifikalı konaklama işletmeleri ile ilgili olarak misafirlerin yapmış olduğu Türkçe yorumlara ulaşmak için "güvenli”, "güvenli turizm" ve "güvenli turizm sertifikası"; İngilizce yorumlara ulaşmak için ise "safe tourism certificate", "certificate" ve "certification" anahtar kelimeleri kullanılmıştır. Araştırma kapsamında toplamda 24 yoruma ulaşılmıştır. Misafirlerin yapmış oldukları yorum sayısına oranla güvenli turizm sertifikalı konaklama işletmelerinin değerlendirildiği yorumların sayısının oldukça az olmasının nedenleri; konaklama işletmelerinin çoğunluğunun bu sertifikayı son dönemde edinmeleri (Ocak-Nisan 2021 tarihleri arasında), covid-19 salgını nedeniyle hem yerli ve hem de yabancı turistlerin seyahatlerinin kısıtlanması ve konaklama işletmelerine yönelik olarak yalnızca güvenli turizm sertifikası ile ilgili değerlendirmeleri içeren yorumların ele alınmasıdır. Bu aşamada araştırmanın birinci aşamasında elde edilen verilerden yararlanarak güvenli turizm sertifikasına sahip işletmelerin büyük çoğunluğunu oluşturan (Bkz. Tablo 2) konaklama tesislerine yönelik olan ve söz konusu işletmelerin yoğunlukta olduğu (Bkz. Tablo 6) illerde faaliyet gösteren işletmelerde konaklayan yerli ve yabancı turistlerin yorumlar araştırmanın kapsamına dâhil edilmiş, diğer şehirlerdeki konaklama işletmelerine yönelik yorumlar araştırmanın kapsamı dışında tutulmuştur. Veriler analiz programından yararlanmayı gerektirecek büyüklükte olmadığından herhangi bir analiz programından destek alınmadan analiz gerçekleştirilmiştir.

İçerik analizi yöntemi ile incelenen misafir yorumlarından elde edilen kodlar gruplandırılmıştır. Bu aşamada veriler sürekli karşılaştırılmış, benzerlikler ve farklılıklar belirlenmiş ve bu doğrultuda kategoriler oluşturulmuştur (Merriam, 2009). Güvenli turizm sertifikalı konaklama işletmelerinin bu sertifikanın gereklilikleri ile uyumlu yönde davranış geliştirip geliştirmedikleri ile ilgili misafir algılarından ve deneyimlerinden yola çıkılarak kategoriler "olumlu yönler" ve "olumsuz yönler" olmak üzere iki ana tema altında birleştirilmiştir. Ayrıca misafir yorumlarından alıntılara yer verilmiştir. Misafir yorumlarından alıntıların gösterilmesinde " $\mathrm{MY}$ " kısaltması kullanılmış ve her bir misafir yorumu için 1'den başlanarak ardışık numaralandırma yapılmıştır (MY1, MY2, MY3...). 


\section{BULGULAR}

\section{Güvenli Turizm Sertifikasına Sahip İşletmelerin Profillerine İlişkin Bulgular}

Tablo 2'de güvenli turizm sertifikasına sahip işletmelere ait bilgilere yer verilmiştir.

Tablo 2. Güvenli turizm sertifikasına sahip işletmelerin profilleri

\begin{tabular}{|c|c|c|c|c|c|}
\hline $\begin{array}{ll}\text { İşletmelerin } & \text { Belgelendirilme } \\
\text { Tarih Aralığı } & \end{array}$ & $\mathrm{N}$ & $\%$ & İşletme Türleri & $\mathrm{N}$ & $\%$ \\
\hline 01.08.2020-31.12.2020 & 267 & 5,3 & Konaklama Tesisi & 3460 & 68,1 \\
\hline 01.01.2021-21.04.2021 & 4817 & 94,7 & Restoran-Kafe & 1566 & 30,8 \\
\hline Toplam & 5084 & 100 & Kültür, Sanat, Kongre Tesisi & 4 & 0,1 \\
\hline $\begin{array}{l}\text { KTB Belgeli } \text { Konaklama } \\
\text { İşletmelerinin Tesis Türlerine } \\
\text { Göre Sınıflandırılması }\end{array}$ & $\mathrm{N}$ & $\%$ & Deniz Turizmi Tesisi & 38 & 0,7 \\
\hline Otel & 1864 & 85,66 & Temalı Park & 7 & 0,1 \\
\hline Butik Otel & 57 & 2,62 & $\begin{array}{l}\text { Kış Turizmi Mekanik Hat } \\
\text { Tesisi }\end{array}$ & 9 & 0,2 \\
\hline Termal Otel & 62 & 2,85 & Toplam & 5084 & 100 \\
\hline Özel Konaklama Tesisi & 132 & 6,07 & $\begin{array}{l}\text { Konaklama Tesisleri ve } \\
\text { Restoran-Kafelerin } \\
\text { Türü }\end{array}$ & $\mathrm{N}$ & $\%$ \\
\hline Müstakil Apart Otel & 23 & 1,06 & & \multicolumn{2}{|c|}{$\begin{array}{l}\text { Konaklama } \\
\text { İşletmesi }\end{array}$} \\
\hline Tatil Köyü & 27 & 1,25 & \multirow{3}{*}{$\begin{array}{l}\text { T.C. Kültür ve Turizm } \\
\text { Bakanlığı Belgeli İşletmeler }\end{array}$} & 2176 & 43,30 \\
\hline Oberj & 2 & 0,09 & & Resto & n/ Kafe \\
\hline Pansiyon & 2 & 0,09 & & 98 & 1,95 \\
\hline Özel Otel-Lokanta & 1 & 0,04 & Toplam & 2274 & 45,25 \\
\hline Dağ Evi & 2 & 0,09 & \multirow{4}{*}{ Belediye Belgeli İşletmeler } & \multicolumn{2}{|c|}{$\begin{array}{l}\text { Konaklama } \\
\text { İşletmesi }\end{array}$} \\
\hline Turizm Kompleksi & 4 & 0,18 & & 1284 & 25,55 \\
\hline Toplam & 2176 & 100 & & \multicolumn{2}{|c|}{ Restoran/ Kafe } \\
\hline $\begin{array}{l}\text { Güvenli Turizm Sertifikasına } \\
\text { Sahip İşletmelerin } \quad \text { Faaliyet } \\
\text { Gösterdiği İller }\end{array}$ & $\mathrm{N}$ & $\%$ & & 1468 & 29,20 \\
\hline Ankara & 356 & 7 & Toplam & 2751 & 54,75 \\
\hline Antalya & 583 & 11,5 & $\begin{array}{lr}\text { KTB Belgeli } & \text { Konaklama } \\
\text { İşletmelerinin } & \text { Yıldız } \\
\text { Sinıflandırması } & \end{array}$ & $\mathrm{N}$ & $\%$ \\
\hline Bursa & 146 & 2,9 & 1 Yildızlı Otel & 13 & 0,7 \\
\hline İstanbul & 1491 & 29,3 & 2 Yildızlı Otel & 118 & 6,1 \\
\hline İzmir & 226 & 4,4 & 3 Yildılı Otel & 638 & 32,7 \\
\hline Muğla & 324 & 6,4 & 4 Yıldızlı Otel & 624 & 32 \\
\hline Diğer & 1958 & 38,5 & 5 Yildızlı Otel & 556 & 28,5 \\
\hline Toplam & 5084 & 100 & Toplam & 1949 & 100 \\
\hline
\end{tabular}


Tablo 2'deki sonuçlar şu şekilde özetlenebilir:

- İşletmelerin büyük çoğunluğunun (\%94,7) güvenli turizm sertifikasını 2021 yılı ocak ve nisan ayları içerisinde edindikleri tespit edilmiştir.

- Güvenli turizm sertifikasına sahip olan işletmelerin büyük çoğunluğunu "konaklama tesisleri" (\%68,1) oluşturmaktadır. İkinci sırada "restoran/kafeler" $(\% 30,8)$ yer almaktadır. İşletmelerin \%1,1'lik kısmını ise sırasıyla "deniz turizmi tesisleri", "kış turizmi mekanik hat tesisleri", "kültür, sanat ve kongre tesisleri" ile "temalı parklar" oluşturmaktadır.

- Güvenli turizm sertifikasına sahip konaklama işletmeleri (T.C. Kültür ve Turizm Bakanlığı belgeli) tesis türlerine göre sinıflandırıldığında, bu kategorideki konaklama tesislerinin büyük çoğunluğunun otel işletmelerinden $(\% 85,66)$ oluştuğu görülmüştür. İkinci sırada özel konaklama tesisleri $(\% 6,07)$ ve üçüncü sırada ise termal oteller $(\% 2,85)$ yer almaktadır.

- Güvenli turizm sertifikasına sahip konaklama işletmeleri ve restoranlar/kafeler belge türlerine (T.C. Kültür ve Turizm Bakanlığı belgeli ve belediye belgeli) göre sınıflandırılmıştır. Bu doğrultuda, işletmelerin büyük çoğunluğunun T.C. Kültür ve Turizm Bakanlığı belgeli konaklama tesislerinden $(\% 43,3)$ oluştuğu, ikinci sırada ise belediye belgeli restoran-kafelerin $(\% 29,20)$ yer aldığı sonucuna ulaşılmıştır. Genel olarak değerlendirildiğinde, bu kategoride güvenli turizm sertifikasına sahip işletmelerin yarısından çoğunun $(\% 54,75)$ belediye belgeli işletme niteliğinde olduğu görülmektedir.

- Güvenli turizm sertifikasına sahip işletmelerin faaliyet gösterdiği illere göre dağılımı incelendiğinde, işletmelerin büyük çoğunluğunun İstanbul'da (\%29,3) faaliyet gösterdiği görülmüştür. Bunu sırasıyla Antalya $(\% 11,5)$ ve Ankara $(\% 7)$ illeri takip etmektedir. Güvenli turizm sertifikasına sahip olan işletmeler Türkiye' de ülke geneline yayıldığından dolayı işletmelerin faaliyet gösterdiği en yoğun illere yer verilmiş, düşük yüzdeye sahip olan iller "Diğer" $(\% 38,5)$ kategorisinde sınıflandırılmıştır.

- Güvenli turizm sertifikasına sahip konaklama işletmeleri (T.C. Kültür ve Turizm Bakanlığı belgeli) yıldız sayılarına göre sınıflandırılırken bu kısımda sadece yıldız sayıları belli olan konaklama işletmeleri dikkate alınmış; T.C. Kültür ve Turizm Bakanlığı belgeli olup da yıldızı olmayan ya da yıldız sayısı belirtilmemiş olan konaklama işletmelerine (butik otel, özel konaklama tesisi, müstakil apart otel, oberj, pansiyon, özel otel-lokanta, dă̆ evi ve turizm kompleksi gibi) yer verilmemiştir. Bu kategorideki konaklama tesislerinin büyük çoğunluğunun üç yıldızlı (\%32,7), dört yıldızlı (\%32) ve beş yıldızlı $(\% 28,5)$ tesislerden oluştuğu görülmüştür.

Araştırmanın birinci aşamasında son olarak, güvenli turizm sertifikasına sahip işletmelerin türleri dikkate alınarak illere göre dağılımı incelenmiştir (Tablo 3). 
Tablo 3. Güvenli turizm sertifikasına sahip işletmelerin türlerine göre illere dağılımı

\begin{tabular}{|c|c|c|c|c|c|c|c|c|}
\hline \multirow[t]{2}{*}{ İller } & \multicolumn{2}{|c|}{ Konaklama Tesisi } & \multirow[t]{2}{*}{ İller } & \multicolumn{2}{|c|}{ Restoran-Kafe } & \multirow[t]{2}{*}{ İller } & \multicolumn{2}{|c|}{$\begin{array}{l}\text { Kültür, Sanat, } \\
\text { Kongre Tesisi }\end{array}$} \\
\hline & $\mathrm{N}$ & $\%$ & & $\mathrm{~N}$ & $\%$ & & $\mathrm{~N}$ & $\%$ \\
\hline Ankara & 202 & 5,8 & Ankara & 153 & 9,8 & Ankara & 1 & 25 \\
\hline Antalya & 495 & 14,3 & Antalya & 79 & 5 & Antalya & 2 & 50 \\
\hline Bursa & 82 & 2,4 & Bursa & 57 & 3,6 & Konya & 1 & 25 \\
\hline İstanbul & 835 & 24,1 & İstanbul & 645 & 41,2 & & - & - \\
\hline İzmir & 135 & 3,9 & İzmir & 90 & 5,7 & & - & - \\
\hline Muğla & 259 & 7,5 & Muğla & 42 & 2,7 & & - & - \\
\hline Diğer & 1452 & 41,8 & Diğer & 500 & 32 & & - & - \\
\hline Toplam & 3460 & 100 & Toplam & 1566 & 100 & Toplam & 4 & 100 \\
\hline \multirow[t]{2}{*}{ İller } & $\begin{array}{l}\text { Deniz } \\
\text { Tesisi }\end{array}$ & Turizmi & \multirow[t]{2}{*}{ İller } & \multicolumn{2}{|c|}{ Temalı Park } & \multirow[t]{2}{*}{ İller } & \multicolumn{2}{|c|}{$\begin{array}{l}\text { KıŞ I urızmı } \\
\text { Mekanik Hat } \\
\text { Tesisi }\end{array}$} \\
\hline & $\mathrm{N}$ & $\%$ & & $\mathrm{~N}$ & $\%$ & & $\mathrm{~N}$ & $\%$ \\
\hline Antalya & 4 & 10,5 & Antalya & 5 & 71,4 & Bursa & 7 & 77,8 \\
\hline Aydın & 1 & 2,6 & İstanbul & 1 & 14,3 & Erzurum & 1 & 11,1 \\
\hline Balıkesir & 1 & 2,6 & Muğla & 1 & 14,3 & Kayseri & 1 & 11,1 \\
\hline İstanbul & 8 & 21,1 & & - & - & & - & - \\
\hline İzmir & 1 & 2,6 & & - & - & & - & - \\
\hline Muğla & 22 & 57,9 & & - & - & & - & - \\
\hline Yalova & 1 & 2,6 & & - & - & & - & - \\
\hline Toplam & 38 & 100 & Toplam & 7 & 100 & Toplam & 9 & 100 \\
\hline
\end{tabular}

Tablo 3 incelendiğinde, konaklama tesisleri $(\% 24,1)$ ile restoran/kafe işletmelerinin $(\% 41,2)$ büyük çoğunluğunun İstanbul'da faaliyet gösterdiği anlaşılmaktadır. Konaklama tesisi türü baz alındığında İstanbul'u sırasıyla Antalya $(\% 14,3)$ ve Muğla $(\% 7,5)$ illeri takip etmektedir. Restoran/kafe kategorisinde ise ikinci sirada Ankara $(\% 9,8)$, üçüncü sırada ise İzmir $(\% 5,7)$ yer almaktadır. Güvenli turizm sertifikasına sahip toplam 4 adet kültür, sanat, kongre tesisinin 2'si (\%50) ve toplam 7 adet temalı parkın 5'i $(\% 71,4)$ Antalya'da faaliyet gösterirken; toplam 9 adet kış turizmi mekanik hat tesisinin 7 'si Bursa' da $(\% 77,8)$ faaliyettedir. Güvenli turizm sertifikalı deniz turizmi tesislerinin ise büyük çoğunluğu $(\% 57,9)$ Muğla ilinde faaliyet göstermektedir.

Güvenli Turizm Sertifikalı Konaklama İşletmelerine Yönelik Olarak Misafirlerin Çevrimiçi Yorumlarına İlişkin Bulgular

Araştırmanın birinci aşamasında belirlenen güvenli turizm sertifikalı konaklama işletmelerine yönelik yerli ve yabancı turistlerin yorumlarının içerik analizi ile incelenmesi sonucunda oluşturulan tema, kategori ve kodlar Tablo 4'te yer almaktadır. 
Tablo 4. Güvenli turizm sertifikalı konaklama işletmelerine yönelik misafir yorumlarından elde edilen kategoriler ve kodlar

\begin{tabular}{|c|c|c|c|}
\hline Tema & Kategoriler & Kodlar & $\mathrm{n}$ \\
\hline \multirow{13}{*}{ 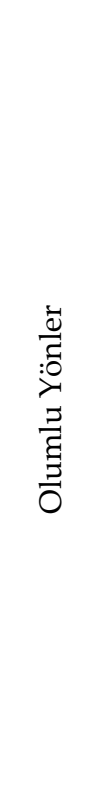 } & \multirow{6}{*}{$\begin{array}{l}\text { Gerekli } \\
\text { uygulanması }\end{array}$} & Ateş ölçme & 1 \\
\hline & & Dezenfektan kullanımı & 4 \\
\hline & & Maske kullanımı & 3 \\
\hline & & Sosyal mesafe kuralı & 3 \\
\hline & & Temizlik/hijyen & 11 \\
\hline & & Havalandırma & 1 \\
\hline & \multirow{3}{*}{ Güven hissetme } & Turistin içinin rahatlaması & 7 \\
\hline & & Huzurlu olma & 3 \\
\hline & & Temizlik hissi & 2 \\
\hline & \multirow{3}{*}{ Hizmet kalitesinin devamlılığ } & İyi servis & 2 \\
\hline & & Yardımsever/ilgili personel & 9 \\
\hline & & Ek hizmetlerin kalitesi ve yeterliliği & 1 \\
\hline & Alınan Önlemler & Animasyon hizmetlerine ara verilmesi & 1 \\
\hline \multirow{10}{*}{ 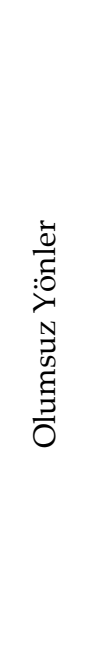 } & \multirow{6}{*}{ Hizmetlerin aksaması } & Teknik aksaklıklar & 1 \\
\hline & & Temizlik/hijyen uygulamalarının yetersizliği & 4 \\
\hline & & Yiyecek-içecek hizmetlerinin yetersizliği & 2 \\
\hline & & Havalandırmanın yetersizliği & 1 \\
\hline & & Sosyal mesafe kuralına uyulmaması & 1 \\
\hline & & Maske kullanılmaması & 3 \\
\hline & \multirow{2}{*}{$\begin{array}{l}\text { Hijyen/temizlik endişesi-bulaş } \\
\text { riski }\end{array}$} & Ortak alanların güvensiz olması & 2 \\
\hline & & Çalışanların kurallara uymaması & 1 \\
\hline & \multirow[t]{2}{*}{ Beklentileri karşılamama } & $\begin{array}{l}\text { İşletme görselinin gerçek görünüm/hizmet ile } \\
\text { uyumsuzluğu }\end{array}$ & 1 \\
\hline & & Kandırılma hissi/hayal kırıklığı & 1 \\
\hline
\end{tabular}

$\overline{\text { Misafir yorumlarının incelenmesi sonucunda "olumlu yönler" teması altında elde }}$ edilen kategoriler "gerekli prosedürlerin uygulanması", "güven hissetme", "hizmet kalitesinin devamlılı̆̆ı" ve "alınan önlemler" olarak ortaya çıkmıştır. Olumsuz yönler teması altında oluşturulan kategoriler ise "hizmetlerin aksaması", "hijyen/temizlik endişesi-bulaş riski" ve "beklentileri karşılamama" şeklindedir. Her bir kategori altında ise misafir yorumlarından elde edilen kodlara yer verilmiştir.

Elde edilen kodlar incelendiğinde, güvenli turizm sertifikalı konaklama işletmelerinin uygulamalarına ilişkin olarak misafirlerin en fazla dikkat ettikleri konu "temizlik ve hijyen" davranışı olmuştur. Bu konu ile birlikte personel ilgisi ve yiyecek-içecek hizmeti gibi hizmetler de ele alınmıştır. Misafirlerin yorumlarından alıntılara aşağıda yer verilmiştir.

MY6, ... Karşılama güler yüzlü ve ilgili. Son konaklamamda rezervasyonumda belirttiğim isteklerim göz ardı edilmemiş olması beni ayrıca memnun etti. Odaları 
bakımlı temizliği sıkıntısız ve hijyenik. COVID-19 tedbirlerine uyuluyor ayrıca güvenli turizm sertifikası var. Kahvaltısı tatminkâr.

MY8, Ilk kez geldik. Ailecek mükemmel bir tecrübe oldu diyebilirim. Personelin güler yüzü ve ilgisi inanılmazdı. En çok dikkat edilen konu hijyendi ki bu dönemde herkes için en önemli unsur bu. Sürekli her yer sterilize ediliyordu. Otel müdürü çok ilgiliydi, güvenli turizm belgesi aldıklarından bahsetti. İçimiz bir kat daha rahat kaldık. Kesinlikle tüm içtenliğimle herkese tavsiye ediyorum.

MY9, A ̆̆ustos ayında bir hafta boyunca muhteşem bir tatil. Huzur, güler yüzlü personel... Yiyecek ve içecekler ile ilgili geniş seçenekleri mevcut. Spa tesislerini $3 \mathrm{kez}$ kullandım, masöz harikaydı ve Türk hamamı denemeye değerdi... Resepsiyon görevlileri ihtiyacını olan her şeyi düzenlemekten mutluluk duyuyor. Otel, Covid sertifikasina sahip ve personel, gereksinimleri karşılamada mükemmel...

MY15, ... Resepsiyondan itibaren kalitesini belli etti tüm eşyalarımız dezenfekte edilerek içeri alındı. ... restorandan ortak kullanım alanlarına oda temizliği havuz temizliği çok iyi... Kovid önlemleri had safhada, zaten güvenli tatil sertifikası var ve biz oradayken sağhlk bakanlı̆̆ından denetime geldiler. Çok memnun kaldım...

MY22, ...Bu sene konakladı̆̆ımız diğer lüks otellerle de kıyasladı̆̆ımda açıkça görüyorum ki, pandemi önlemlerine en büyük yatırımı yapan otel burasıydı desem yalan olmaz. Zaten biz oradayken, haberini aldık ki, güvenli tesis sertifikası almaya 100 üzerinden 100 puan alarak hak kazanmışlar. Odanız sterilize edilmiş ve kapısı mühürlenmiş halde sizi bekliyor, kapıdan girerken o etiketi ilk siz açıyorsunuz. Bavullarını da henüz check-in esnasında ozon püskürtülerek sterilize ediliyor. Kullanacă̆ını kalemden, aklınza gelecek ne varsa, odadaki havlulardan, havuz ve deniz havlularma kadar her şey...

Yorumlar incelendiğinde misafirlerin "gerekli prosedürlerin uygulanması" ve "hijyen/temizlik endişesi-bulaş riski" kategorileri altında yer alan kodlarla ilgili olarak hem işletmede konaklayan diğer turistler açısından hem de çalışanlar açısından değerlendiren ifadelere yer verdiği görülmüştür. Misafirler örneğin "maske, dezenfektan kullanımı" gibi hijyen ve temizlik uygulamalarının bulaş riskinin ortamdaki herkesten kaynaklanabileceği düşüncesiyle hem işletme çalışanları hem de işletme de konaklayan diğer misafirler tarafından dikkat edilmesi gereken konular olduğunu belirtmişlerdir. Katılımcılardan bazılarının ifadelerinden alıntılara aşağıda yer verilmiştir.

MY21, ..."Güvenli Turizm" sertifikasına sahip olmasına ră̆men sizi Covid-19'a karşı güvenli hale getirmek için gerekli önlemleri almamaktadır. En tipik örnek restorandadır. Yemek servisi kapalı alanda yapilır ve bu alanda herkesin maske takmasi gerekir. Maalesef misafirlerin yarısı maske takmıyor ve otel çalışanları tek bir kişiyi uyarmadı... Bu dikkatsiz yaklaşımın yemek alırken Covid-19 virüsüne yakalanma riskini artırdığını düşünüyorum. Öte yandan, tüm çalışanlar her zaman maske takarlar. Birkaç kişinin burnunun açık olduğu sadece bir veya iki örnek vardı... 
MY17, Geçen hafta çok rahatlatıcı bir aile tatilinden döndük. Pandemi nedeniyle, otel kaldığımız önceki günlere göre daha sessizdi. Gerekli tüm sosyal mesafe ve güvenlik önlemlerini aldılar ve sergilenen devlet güvenlik sertifikasını görmek güven vericiydi. ...Resepsiyonda çok hoş karşılandık. Bar ve restoran otelin kalbinde yer alıyor ve her zamanki yüksek standartta samimiyet ve mükemmel hizmet sunuyor...

Misafirler işletmelerin güvenli turizm sertifikası kapsamında uygulamalarına ilişkin değerlendirmeler yaparken "çalışanların ilgili, güler yüzlü ve yardımsever olması", "yiyecek içecek hizmetlerinin yetersizliği" ve "işletme görselinin gerçek görünüm ile uyumsuzluğu" kodlarını güvenli turizm sertifikası kapsamında ele almış, işletmelerin uygulamaları ile ilişkilendirmiş ve bu konulara yönelik memnuniyetlerini ve memnuniyetsizliklerini de dile getirmişlerdir. Katılımcılardan bazılarının ifadelerinden alıntılara aşağıda yer verilmiştir.

MY1, ... Otele girişte termal kamera ile ateşimiz ölçüldü. Ardından dezenfektan ve takmamız için maske verildi. Maskelerimizi özellikle insan yoğunluğu bulunan resepsiyonda ve ana restoranda takmamiz hususunda telkinlerde bulunuldu. O an güvenli tatil için doğru adreste olduğumuzu anladım. Ardından tertemiz odamıza yerleştik. Kahvaltı için ana restorana ilerlediğimizde kapıda yine ateşimiz ölçüldü... İçim rahat ve huzurlu. Keyfimiz yerinde ve en önemlisi tüm aile güvendeyiz. Ortak alanda bulunan su dolabının hemen yanında dezenfektan var. Otelin yüzölçümü de büyük olduğu için sosyal mesafe kuralı da uygulanabiliyor. Ayrıca pandemi süreci bahane edilip servisten ve hizmet kalitesinden en ufak ödün verilmemiş...

MY12, ...Tesisin misafirlerini olabildiğince güvende ve rahat hissettirmek ve herhangi bir Covid-19 riskini azaltmak için aldı̆̆ı önlemler harika. İsletme, herkesin să̆lığını korumak için alınan tedbirler için en yüksek standartları uyguladığımı belirten özel bir sertifikaya sahip. Personel güler yüzlü ve çok yardımsever. Plaj ve havuz alanları temiz ve misafirperver. Yemekler her zamanki gibi lezzetli...

MY14, ...Çalışanlar kurallara uymak için özen gösteriyor, maskelerini çıkarttıklarını hiç görmedim ancak uzun süreli çalıştırıldıkları yüz ifadelerindeki yorgunluktan anlaşılıyordu. Ellerinden geleni yapmaya çalıştıkları için her birine ayrı ayrı teşekkür ederim. Otelde konaklayan yabancı müşteriler ise ortak alanlarda maskelerini hiç takmıyorlardı. Güvenli seyahat belgesi alan bir işletmenin buna daha çok dikkat etmesi gerekirdi. Ailecek bizi en çok zorlayan restoran hizmeti oldu. Yemekler ancak bu kadar lezzetsiz ve özensiz yapılabilir. Kahvaltı bir şekilde idare edilebilir ancak ana restorandaki öğle ve akşam yemekleri gerçekten işletme tarafindan ciddi bir şekilde gözden geçirilip, düzeltilmesi gerekiyor...

MY23, Covid-19 sebebiyle emin olamadığımız tatilimize X otelde başlamak istedik. Güvenli Turizm Sertifikası olması sebebiyle çekici geldi... Odamız ise standart odaydı ve tertemizdi... Çok beklenti içinde olmamamıza rağmen yemekler oldukça güzeldi ve menü tahminimizden zengindi. Fazlasıyla doyduk. Personel çok güler yüzlü ve yardımcıydı. Sürekli ellerinde dezenfektan ile kalkan müşterilerin ardından masaları sandalyeleri dezenfekte ettiler... 
MY5, Fiyat performans olarak konakladiklarım arasında ilk üçe girebilecek otel... Girişte personel ilgili ve güler yüzlü. Korona tedbirleri uygulanıyor ve otelin güvenli turizm sertifikası var. Odaları ferah temiz ve hijyenik. Kahvaltıda personel ilgili ve güler yüzlü. Kahvaltı taze ve yeterince.

Güvenli turizm sertifikalı konaklama işletmelerine ilişkin ulaşılabilen misafir yorumlarının çoğunluğunun sürece ve uygulamalara ilişkin olumlu yönde görüş bildirdiği sonucuna ulaşılmıştır. Ancak konuyla ilgili olumsuzluk içeren ve memnuniyetsizliklerin dile getirildiği yorumlara da rastlanmıştır. Bu yorumlardan alıntılara da aşağıda yer verilmiştir.

MY7, Sabah kalktığınızda sıcak su akmıyor, duş alamıyorsunuz, gece ise sıcak hava kaloriferi arızalanmış, odaya soğuk hava basmış. Otelden nezle olarak ayrıldım... Işs toplantısına burnumun akmaya başlaması nedeniyle, nezle olduğumdan katılamayıp, geri dönmek zorunda kaldım. Korona şüphesiyle de kendimi 3 gün izole etmek zorunda kalmamda cabası. Güvenli Turizm Sertifikası var ama restoran, pek güvenli değil. Restoran çalışanları Covid-19 kurallarına uymuyor.

MY11, Otelden nasıl kaçtığımızı bilemedik... Güya covid-19 döneminde güvenli otel/temiz otel sertifikası almışlar... Sadece eldiven takarak temizlik ve hijyen sağlanmıyor. Eldivenin sürekli değiştirilmesi gerekiyor... Gerek Instagram gerekse de tur sitelerinde yer alan fotoğrafların gerçekle hiçbir alakası yok. Yemekler o kadar kötü ki doğru düzgün yemek bile yiyemedik... Kaldığımız odanın bile fotoğraflardaki odalarla bir alakası yoktu... Influencerlarla nasıl bir anlaşma yapılmışsa, el birliği ile hayali bir tatil satılıyor ve siz bütün bir yıl beklediğiniz kısacık tatilinizin bu kandırmaca ile nasıl yerle bir edildiğini görüyorsunuz.

MY13, ...Temizlik: Otel hiç temizlenmemiş, bir önceki gece çorba kepçeleri ve çorba dolu kaseler tezgâha oturtulmuş ve etraflarında sinekler vizlldıyor. Bu otelin nasıl Covid güvenli sertifikası almayı başardı̆̆ını bilmiyorum, otel arazilerinde veya sosyal mesafelerde maske yok, şezlonglar, havuzdaki masalar hiç temizlenmemiş. Oteldeki asansör düğmeleri, korkuluklar vb. temas noktaları asla temizlenmiyor. Yatak odalarn da düzgün temizlenmemiş, yataklar yapılmış ve hepsi bu kadar. Yerler süpürülmüyor, banyolar asla temizlenmiyor, ĕger şanslıysanız tuvalet rulolarn günde bir adet veriliyor...

MY24, Şu an 3 günlük tatilin son günü olduğu için şükrediyoruz. Otele güya güvenli turizm sertifikası var diye rezervasyon yaptık. Otel korkunç, bakımsız ve eski... Odalar çok pis ve bakımsız muhtemelen yapıldı̆̆g ilk günden sonra bir çivi bile çakılmamış. ...değiştirsinler diye verdiğimiz havlunun yerine daha kirlisi geldi. Ne söyleyeceğimi bilemiyorum insanlar buraya nasıl bayılıyorlar anlamış değilim. Tek güzel detay denizi temiz ve berrak. Ama genel olarak kesinlikle tavsiye etmem!

\section{SONUÇ, TARTIŞMA VE ÖNERİLER}

Bu çalışmada, Türkiye'de güvenli turizm sertifikalı işletmelerin profilleri belirlenmeye çalışılmış ve bu sertifikaya sahip olan konaklama işletmelerine yönelik çevrimiçi misafir yorumları incelenmiştir. Araştırmanın bulguları genel olarak 
değerlendirildiğinde, Türkiye'de güvenli turizm sertifikalı işletmelerin büyük bölümünün konaklama tesislerinden oluştuğu belirlenmiştir. Böyle bir sonucu doğal karşılamak gerekmektedir. Çünkü konaklama işletmeleri turizm endüstrisinin temel öğelerinden biri olarak kabul edilmektedir (Tarlan ve Tütüncü, 2001; Demirtaş, 2010; Akgündüz ve Bardakoğlu, 2012). Öte yandan güvenli turizm sertifikalı restoran ve kafelerin \%30,8'lik bir orana sahip olması ilgi çekicidir. Türkiye' de çok sayıda restoran ve kafenin bulunduğu dikkate alındığında bu oranın daha yüksek olması beklenebilirdi. Ancak güvenli turizm sertifikasına sahip olabilmek için işletmeler tarafından yerine getirilmesi gereken ve belli bir süreci içeren çok sayıda kriterin bulunması ve bu kriterlerin her birinin maddi ve beşerî açıdan ciddi kaynak gereksinimi gerektirdiği düşünüldügüunde Türkiye'deki bazı restoran ve kafelerin henüz bu kriterleri yerine getiremedikleri anlaşılmaktadır. Diğer yandan restoran ve kafelerin covid-19 salgınının önemli bir bölümünde kapalı kalmaları da bu oranın düşük çıkmasında etkili olmuş olabilir.

Çalışmamızda ortaya konan, güvenli turizm sertifikasına sahip olan konaklama işletmelerinin çok büyük bir bölümünün $(\% 85,66)$ otel işletmelerinden oluştuğu yönündeki bulguyu da doğal karşılamak gerekmektedir. Nitekim 2020 yılı itibariyle Türkiye'de Kültür ve Turizm Bakanlığı'ndan işletme belgeli konaklama yatak kapasitesi 1.020.985 olup, bunun 862.163'üne otel işletmeleri sahiptir. Başka bir ifadeyle, 2020 yılı itibariyle Türkiye'de Kültür ve Turizm Bakanlığı'ndan işletme belgeli toplam 4218 konaklama tesisinin 3116'sı otel işletmelerinden oluşmaktadır (https://yigm.ktb.gov.tr/TR-201131/tesis-istatistikleri.html).

Güvenli turizm sertifikasına sahip işletmelerin büyük çoğunluğunun T.C. Kültür ve Turizm Bakanlığı belgeli konaklama tesislerinden oluşması dikkat çekici bir diğer bulgudur. 2020 yılı itibariyle Türkiye'de Kültür ve Turizm Bakanlığı'ndan işletme belgeli konaklama tesisi sayısı 4218, belediye belgeli konaklama tesisi sayısı ise 8609'dur (https://yigm.ktb.gov.tr/TR-201131/tesis-istatistikleri.html). Belediye belgeli konaklama tesisleri sayısının ilgili bakanlık belgeli konaklama tesisleri sayısından yaklaşık iki kat daha fazla olmasına rağmen güvenli turizm sertifikalı konaklama işletmelerinin \%43,3'ünün T.C. Kültür ve Turizm Bakanlığı belgeli konaklama tesislerinden oluştuğu saptanmıştır. Güvenli turizm sertifikalı belediye belgeli konaklama tesislerinin oranının ise \%25,55 olduğu görülmüştür. Tam tersine, Türkiye'de güvenli turizm sertifikalı belediye belgeli restoran ve kafelerin oranı $\% 29,20$ olarak tespit edilirken, ilgili bakanlıktan belgeli restoran ve kafelerin sadece \%1,95'inin güvenli turizm sertifikasına sahip olduğu saptanmıştır.

Güvenli turizm sertifikasına sahip olan T.C. Kültür ve Turizm Bakanlığı belgeli konaklama tesislerinin büyük bölümünün sırasıyla üç, dört ve beş yıldızlı tesislerden oluştuğu tespit edilmiştir. Bu bulgu da ilgili literatür bilgilerini doğrulamaktadır. Nitekim Türkiye'de ilgili bakanlıktan belgeli konaklama tesislerinin sayısı 2020 yılı itibariyle 4218 olup, bu tesislerden 52'si bir yıldızlı, 381'i iki yıldızlı, 1110'u üç yıldızlı, 869'u dört yıldızlı ve 704'ü beş yıldızlı tesis niteliği taşımaktadır (https://yigm.ktb.gov.tr/TR-201131/tesis-istatistikleri.html). Türkiye'de güvenli turizm 
sertifikalı bir yıldızlı konaklama işletmelerinin oranı \%0,7 iken, bu oran iki yıldızlı konaklama tesislerinde \%6,1'dir. Dolayısıyla işletme ölçeği büyüdükçe güvenli turizm sertifikalı konaklama tesislerinin sayısı artmaktadır. Böyle bir bulgu, güvenli turizm sertifikası için gerekli olan kriterleri yerine getirme bakımından orta ve büyük ölçekli konaklama tesislerinin daha üstün özelliklere sahip oldukları şeklinde yorumlanabilir.

Türkiye' de güvenli turizm sertifikasına sahip olan işletmelerin illere göre dağılımında İstanbul \%29,3'lük bir oranla diğer illere kıyasla öne çımıştır. İstanbul'u en yakın takip eden il olan Antalya \%11,5'lik orana sahiptir. Üçüncü sırada ise Muğla $(\% 6,4)$ yer almıştır. Türkiye'de ilgili bakanlıktan belgeli konaklama tesislerinin illere göre dağılımında 07.05.2021 tarihi itibariyle ilk üç sırayı Antalya (806 tesis), İstanbul (652 tesis) ve Muğla (415 tesis) oluşturmaktadır (https://yigm.ktb.gov.tr/TR-201136/turizmyatirim-ve-isletme-bakanlik-belgeli-tesis-istati-.html). Aynı tarih itibariyle belediye belgeli konaklama tesislerinde ise siralama İstanbul (1433 tesis), Antalya (1026 tesis) ve Muğla (901 tesis) şeklindedir (https://yigm.ktb.gov.tr/TR-201137/belediye-belgelitesis-istatistikleri.html). Bu araştırma kapsamında Türkiye'de güvenli turizm sertifikalı işletmelerin ağırlıklı olarak İstanbul'da toplanması talep yapısıyla açıklanabilir. İstanbul' daki konaklama tesislerinin büyük bölümü şehir oteli olup, bu tesislerin tipik özelliği turizm talebinin mevsimsel dalgalanmalarından daha az etkilenmeleridir. Sayfiye otelleri ise, mevsime bağlı olarak turizmin talep yoğunluğundan daha fazla etkilenir. Dolayısıyla İstanbul'da faaliyet gösteren konaklama tesisleri, güvenli turizm sertifikası edinme noktasında daha hızl davranma ihtiyacı duymuş olabilir. Araştırma kapsamında Türkiye' de işletmelerin büyük çoğunluğunun $(\% 94,7)$ güvenli turizm sertifikasını 2021 yılı ocak ve nisan ayları içerisinde edindikleri tespit edilmiştir. Belirtilen tarihler özellikle yazlık bölgelerde faaliyet gösteren sayfiye otelleri için düşük sezon olarak nitelendirilebilir. Dolayısıyla ileride yapılacak benzer araştırmalarda Antalya ve Muğla illeri lehine sonuçların ortaya çıkması yüksek bir ihtimal olarak görülmektedir.

Araştırma kapsamında ulaşılabilen misafirlerin yorumları değerlendirildiğinde, salgın ile ilgili olarak temizlik-hijyen konusunu ele aldıkları dikkat çekmektedir. Çalışanların ilgili ve özverili davranışlarının misafir memnuniyeti üzerinde oluşturduğu olumlu etki de yorumların önemli bir parçası olmuştur. Bunun yanı sıra sosyal medya (influencerlar) aracılığıyla yapılan tanıtımların hayal kırıklığına yol açtığı da bir misafir yorumunda dile getirilmiştir. Bu sebeple yapılan tanıtımların gerçeklerle uyumlu olmasının misafirlerin algılarında ve tavsiye davranışlarında etkili olabileceğini ifade etmek mümkündür. Nitekim, Özaltın Türker ve Ertürk de (2020) yapmış oldukları çalışmada salgın sonrası turizmde en fazla üzerinde durulacak kavramların hijyen, tanıtım, güven ve kişiye özel hizmet olacağını belirtmektedir. Ayrıca yazarlar, salgınla birlikte turistlerin konaklama işletmelerinden hijyen, sosyal mesafe, sertifikasyon, doktor hizmeti, rutin ilaçlama, çalışan hijyeni gibi beklentilerinin daha da artacağını ve bunun da "Güvenli Turizm Sertifikası" programı sayesinde aşılabileceğini ileri sürmektedir. Yazıcı Ayyıldız'ın (2020) otel yöneticileri üzerinde yapmış olduğu çalışmada, covid-19 salgın döneminde güvenlik ve hijyen konularında alınan tedbirlerin süreklilik arz etmesi gerektiğini ifade etmesi de 
araştırmanın sonuçlarını destekler niteliktedir. Benzer şekilde, Sezen Doğancılı (2020) covid-19 salgını sonrası turizm desteklerine yönelik yapmış olduğu çalışmasında, turizm sektöründe faaliyet gösteren her iş kolu için sertifikalandırmanın ve hijyen temalı konseptlerin ön plana çıkarılması gerektiğine dikkat çekmektedir.

İşletmelerin güvenli turizm sertifikasına sahip olmasının misafirlerin de kendilerini güvende hissetmesinde, işletmeye ve çalışanlarına güven duymada oldukça etkili olduğu sonucuna ulaşılmıştır. Bununla ilgili olarak misafirlerin "işletmenin yapmış olduğu uygulamalar ile bu sertifikayı sonuna kadar hak ettiği" gibi ifadelerine rastlanmaktadır. Dolayısıyla sertifikanın gerektirdiği koşulların işletmelerce uygulanmasının işletmenin tekrar tercih edilmesinde etkili olabileceği gibi, tavsiye davranışları sayesinde gelecekte tercih edecek misafirler için de önem arz etiği düşünülmektedir. Erdoğan ve Yamaç Erdoğan da (2020) T.C. Kültür ve Turizm Bakanlığı perspektifinden turizmde normalleşme faaliyetlerini değerlendirdikleri çalışmalarında, güvenli turizm sertifikasının covid-19 salgını sonrası da geçerliliğini koruyacağını ve sürekli yapılacak denetlemelerle bir çatı sertifikasyonu haline getirileceğini ifade etmektedir. Ayrıca, turizm işletmelerinin sertifikalandırılmasının uluslararası algıyı yönlendirmede de rol oynayabileceği ileri sürülmektedir. Eşitti ve Özdemir (2020) yaptıkları çalışmada, güvenli turizm sertifikasına sahip konaklama tesislerinin güvenli turizm sertifikasyon programı kapsamında kriz yönetimi ve sürdürülebilirliğe ilişkin tutumları incelemişlerdir. Çalışma sonuçlarına göre, konaklama tesislerinin güvenli turizm sertifikasına sahip olmalarının, çalışanlara ve misafirlerine güven verme açısından önemli olduğu belirlenmiştir.

Her araştırmada olduğu gibi bu araştırmanın da birtakım sınırlılıkları bulunmaktadır. Her şeyden önce bu araştırmanın bulguları verilerin toplandığı dönemle sınırlıdır. Türkiye'de güvenli turizm sertifikasyon programinın yürürlükte olduğu düşünüldüğünde, rakamların sürekli güncelleneceğini dikkate almak gerekecektir. Öte yandan bu araştırma Türkiye'de güvenli turizm sertifikalı işletmelerin profillerinin ikincil verilerden yararlanılarak ortaya koyulmasıyla sınırlıdır. Sonraki araştırmalarda bu süreçte işletmelerin yaşadıkları sorunlar ve çözüm önerileri üzerine görgül çalışmalar yürütülebilir. Bu görgül araştırmalar, güvenli turizm sertifikasyon programının işletmelere sağladığı faydalar üzerine de odaklanabilir. Diğer yandan, bu araştırma kapsamında incelenen misafirlerin çevrimiçi yorumları da verilerin toplandığı dönemle sınırlıdır. Türkiye' de güvenli turizm sertifika programının devam ettiği, kriterleri yerine getiren işletmelere her gün bir yenisinin eklendiği, turizmde yaz sezonunun yaklaştı̆̆ı ve covid-19 tedbirleri kapsamında meydana gelebilecek esneklikler de hesaba katılarak turistlerin konaklama tesislerine olan taleplerinin artış göstereceği öngörülebilir. Bu nedenle sonraki araştırmalarda misafirlerin çevrimiçi yorumlarının daha geniş bir örneklem grubundan toplanması mümkün olabilecektir. Bununla birlikte, bu araştırmada sadece tripadvisor.com internet sitesinde konuyla ilgili yer alan misafir yorumları incelenmiştir. Turistlerin seyahat ve konaklama deneyimlerini paylaştığı çok başka internet sitelerinin de olduğu bilinmektedir. Sonraki araştırmalarda bu internet siteleri de dikkate alınarak konuyla ilgili çevrimiçi yorum yapan örneklem grubu genişletilebilir. Diğer taraftan, bu araştırmada sadece 
güvenli turizm sertifikalı konaklama işletmelerine yönelik yapılan çevrimiçi yorumlar üzerine odaklanılmıştır. Bu da çalışmanın bir sınırlılığı olarak görülebilir. Sonraki araştırmalarda güvenli turizm sertifikasına sahip diğer işletmelere yönelik yapılan çevrimiçi müşteri değerlendirmelerinin incelenmesi de literatüre katkı sağlayabilir. Son olarak, ileride yapılacak araştırmalarda konuyla ilgili veriler anket veya görüşme tekniğiyle toplanarak konu farklı bakış açılarıyla ele alınabilir.

Hakem Değerlendirmesi: Dış bağımsız.

Teşekkür: Katkılarından dolayı hakemlere teşekkür ederiz.

Destek Bilgisi: Herhangi bir kurum ve/veya kuruluştan destek alınmamıştır.

Çıkar Çatışması: Yazarlar arasında çıkar çatışması yoktur.

Etik Onayı: Bu çalışmanın tüm hazırlanma süreçlerinde etik kurallara riayet edildiğini yazar(lar) beyan eder. Aksi bir durumun tespiti halinde Güncel Turizm Araştırmaları
Dergisi'nin hiçbir sorumluluğu olmayıp, tüm sorumluluk makale yazar(lar)ına aittir.

Bilgilendirilmiş Onam Formu: Tüm taraflar kendi rızaları ile çalışmaya dâhil olmuşlardır.

Etik Kurul Onayı: Çalışma kamuya açık ikincil verilerin kullanılmasiyla oluşturulmuştur.

Araştırmacıların Katkı Oranı: Yazarlar çalışmaya eşit oranda katkı sağlamıştır.

Veri Kullanılabilirlik Beyanı: Araştırma verileri paylaşılmamıştır.

\section{KAYNAKÇA}

Açıksözlü, Ö. ve Bozok, D. (2018). Türk hamamlarında hijyen ve sanitasyonun turist sağlı̆̆1 açısından ele alınması: Antalya ili örneği. ÇOMÜ Uluslararası Sosyal Bilimler Dergisi, $3(1), 1-20$.

Akgündüz, Y. ve Bardakoğlu, Ö. (2012). Turistlerin eğitim durumu ve cinsiyetlerinin otel seçimine etkisi: İzmir'de bir araştırma. Dokuz Eylül Üniversitesi Sosyal Bilimler Enstitüsü Dergisi, 14(4), 13-29.

Akoğlan Kozak, M. (1997). Kat hizmetleri departmanında hijyenin önemi. Anatolia: Turizm Araştırmaları Dergisi, 8(Eylül-Aralık), 32-37.

Aktaş, A. ve Özdemir, B. (2012). Otel İşletmelerinde Mutfak Yönetimi. Ankara: Detay Yayıncilik.

Akyürek, S. ve Kutukız, D. (2020). Experiences of gastro tourists: A qualitative research in the scope of gastronomy tours. Journal of Tourism and Gastronomy Studies, 8(4), 33193346.

Arendt, S. W., Roberts, K. R., Strohbehn, C., Arroyo, P. P., Ellis, E. ve Meyer, J. (2014). Motivating foodservice employees to follow safe food handling practices: Perspectives from a multigenerational workforce. Journal of Human Resources in Hospitality \& Tourism, 13(4), 323-349.

Bauer, I., (2008). The health impact of tourism on local and indigenous populations in resource-poor countries. Travel Medicine and Infectious Disease, 6, 276-291.

Bulduk, S. ve Bulduk, E. Ö. (2018). Gıda ve Personel Hijyeni. Ankara: Detay Yayıncılık.

Chang, H. (S.), Capuozzo, B., Okumus, B. ve Cho, M. (2021). Why cleaning the invisible in restaurants is important during COVID-19: A case study of indoor air quality of an open-kitchen restaurant. International Journal of Hospitality Management, 94, 1-12. 
Çetinkaya, Ö., Özer, Y. ve Kandemir Altuner, G. (2020). Covid-19 sürecinde turistik seyahat risk algısı ve hijyen-güvenlik algısının değerlendirilmesi. To \& Re, 2(2), 78-83.

Demir, C. ve Çevirgen, A. (2006). Turizm ve Çevre Yönetimi Sürdürülebilir Gelişme Yaklaşımı. Ankara: Nobel Yayın Dağıtım.

Demir, Ş. Ş. (2020). Türkiye'de Covid-19 sürecinde turizmle ilgili yayınlanan genelgelerin analizi. International Journal of Social Sciences and Education Research, 6(4), 491-500.

Demirtaş, N. (2010). Otel İşletmeciliği. Ankara: Ankara Üniversitesi Uzaktan Eğitim Yayınları, Yayın No: 67.

Dündar, Y., Silik, C. E. ve Ilgaz, B. (2020). Antalya'da yer alan konaklama tesisleri yöneticilerinin COVID-19 kapsamında alınabilecek tedbirler üzerine görüşleri. İşletme Araştırmaları Dergisi, 12(4), 3776-3794.

Erdoğan, Ç. ve Yamaç Erdoğan, Z. (2020). Turizmin COVID-19 direnci: Bakanlık perspektifinden turizmde normalleşme faaliyetleri-I. Çeyrek. Türk Turizm Araştırmaları Dergisi, 4(4), 3358-3377.

Eşitti, B. ve Özdemir, C. (2020). Güvenli turizm sertifikasyon programının kriz yönetimi ve sürdürülebilirlik açılarından ele alınması. Journal of Humanities and Tourism Research, (Özel Say1 5), 76-89.

Giritlioğlu, İ. ve Kızılcık, O. (2016). Turizme hizmet sunan pastane işletmelerinde çalışan dondurma üretim personelinin hijyen ve gida güvenliğine ilişkin bilgi ve uygulama düzeyi üzerine bir araştırma. Mehmet Akif Ersoy Üniversitesi Sosyal Bilimler Enstitüsü Dergisi, 8(15), 301-319.

Göktan, D. ve Tunçel, G. (2016). Temel Gıda Hijyeni. İzmir: Sidas.

Gössling, S., Scott, D. ve Hall, C.M. (2021) Pandemics, tourism and global change: A rapid assessment of COVID-19. Journal of Sustainable Tourism, 29(1), 1-20.

Gül, K., Gül, M. ve Saatcı, G. (2018). Konaklama sektöründe hijyen kaynaklı müşteri sağlık riski alg1sı: Bursa ve Diyarbakır'daki tesislere yönelik kıyaslama. Seyahat ve Otel İşletmeciliği Dergisi, 15(1), 23-37.

Jovanović, S., Janković-Milić, V. ve Ilić, I. (2015). Health and hygiene importance for the improvement of tourism sector competitiveness in Serbia and the South-Eastern Europe countries. Procedia Economics and Finance, 19, 373-382.

Karaçor, B. ve Tanrısever, C. (2020). Konaklama işletmelerinde kullanılan sertifikasyonların pazarlama, doluluk ve verimlilik üzerine etkisi. Güncel Turizm Araştırmaları Dergisi, $4(2), 278-296$.

Karadeniz, E., Beyaz, F. S., Ünlübulduk, S. N. ve Kayhan, E. (2020). Covid-19 salgınının turizm sektörüne etkilerinin ve uygulanan stratejilerin değerlendirilmesi: Otel yöneticileri üzerinde bir araştırma. Türk Turizm Araştırmaları Dergisi, 4(4), 3116-3136.

Kaushal, V. ve Srivastava, S. (2021). Hospitality and tourism industry amid COVID-19 pandemic: Perspectives on challenges and learnings from India. International Journal of Hospitality Management, 92, 1-9.

Marwaha, K. (2007). Food Hygiene. New Delhi: Gene-Tech Books.

Merriam, S. B. (2009). Qualitative Research A Guide to Design and Implementation. (2. 
Edition). San Francisco: Josey-Bass A Wiley Imprint.

Mostafanezhad, M. (2020). Covid-19 is an unnatural disaster: Hope in revelatory moments of crisis. Tourism Geographies, 22(3), 639-645.

Naumov, N., Varadzhakova, D. ve Naydenov, A. (2020). sanitation and hygiene as factors for choosing a place to stay: Perceptions of the Bulgarian tourists. Anatolia, 1-4.

Notermans, S. ve Powell, S. C. (2005). Introduction. Lelieveld et al. (Ed.), içinde Handbook of Hygiene Control in the Food Industry (s. 1-24). Abington: Woodhead Publishing Limited.

Özaltın Türker, G. ve Ertürk, N. (2020). COVID-19'un konaklama işletmelerine etkileri: yöneticiler perspektifinden bir değerlendirme. Turizm Ekonomi ve İşletme Araştırmaları Dergisi, 2(2), Aralık, 89-101.

Özkoçak, V., Koç, F., Gültekin, T. (2020). Pandemilere antropolojik bakış: Koronavirüs (Covid19) örneği. Turkish Studies, 15(2), 1183-1195.

Sanlıer, N., Cömert, M. ve Durlu-Özkaya, F. (2010). Hygiene perception: Condition of hotel kitchen staffs in Ankara, Turkey. Journal of Food Safety, 30, 415-431.

Satar, İ. ve Güneş, G. (2017). Turizm sertifikasyonu: Ankara Radisson Blu Otel'de örnek uygulama. Ankara Üniversitesi Sosyal Bilimler Dergisi, 8(2), 28-46.

Sezen Doğancılı, O. (2020). COVID-19 salgını sonrası turizm destekleri. Türk Turizm Araştırmaları Dergisi, 4(3), 2808-2820.

Shuting, T., Kang, B. ve Kim, H-S. (2018). Understanding the food hygiene of cruise through the big data analytics using the web crawling and text mining. Culinary Science \& Hospitality Research, 24(2), 34-43.

Tarlan, D. ve Tütüncü, Ö. (2001). Konaklama işletmelerinde başarım değerlemesi ve iş doyumu analizi. Dokuz Eylül Üniversitesi Sosyal Bilimler Enstitüsü Dergisi, 3(2), 141163.

Thanh, T. V. ve Kirova, V. (2018). Wine tourism experience: A netnography study. Journal of Business Research, 83, 30-37.

Tripadvisor. (2021). https://tripadvisor.mediaroom.com/tr-about-us. (Erişim Tarihi: 15 Mays 2021).

Türkiye Turizm Tanıtım ve Geliştirme Ajansı (2021a), https://www.tga.gov.tr/turkiyeninguvenli-turizm-programi-hakkinda/ (Erişim Tarihi: 30 Ocak 2021).

Türkiye Turizm Tanıtım ve Geliştirme Ajansı (2021b), https://tga.gov.tr/ (Erişim Tarihi: 21 Mayis 2021).

Türkiye Turizm Tanıtım ve Geliştirme Ajansı (2021c), https://www.tga.gov.tr/guvenli-turizmprogrami-belgelendirme-kriterleri/ (Erişim Tarihi: 21 Mayıs 2021).

Wang, C., Zhang, J., Sun, J., Chen, M. ve Yang, J. (2020). Public environmental facilities: Hygiene factors for tourists' environmental behaviour. Environmental Science and Policy, 106, 40-47.

Xiang, Z., Schwartz, Z., Gerdes, J. H. ve Uysal, M. (2015). What can big data and text analytics tell us about hotel guest experience and satisfaction? International Journal of Hospitality Management, 44, 120-130. 
Yazıcı Ayyıldız, A. (2020). COVID-19 salgın döneminde otellerin pazarlama stratejileri: Kuşadası örneği. BMIJ, 8(3), 3328-3358.

Y1lmaz, Y. (2012). Otel ve Yiyecek-İçecek İşletmelerinde Ziyafet Organizasyonu ve Yönetimi. Ankara: Detay Yayıncilık.

https://yigm.ktb.gov.tr/TR-201131/tesis-istatistikleri.html (Erişim Tarihi: 22 Mayıs 2021).

https://yigm.ktb.gov.tr/TR-201136/turizm-yatirim-ve-isletme-bakanlik-belgeli-tesis-istati.html (Erişim Tarihi: 22 Mayıs 2021).

https://yigm.ktb.gov.tr/TR-201137/belediye-belgeli-tesis-istatistikleri.html (Erişim Tarihi: 22 Mayıs 2021). 